\title{
Macau: espaço geográfico e espaço literário-pessoal na poesia de Yao Jingming
}

Gustavo Infante $(\mathrm{UoB})^{1}$

Resumo: Este breve artigo procura dar a conhecer alguma da poesia em português do poeta chinês Yao Jingming, na sua articulação como Macau como espaço geográfico e espaço literário e pessoal. Numa Macau pós-administração portuguesa, sugere-se que esta poesia, bem como a produção literária em português em Macau, constituam aquilo que eu designaria como literatura chinesa de expressão portuguesa.

Palavras-chave: espaço; geografia; eu; outro; morte.

Na produção literária em língua portuguesa de Macau, existe um caso que já não poderemos designar como singular, mas que é, isso sim, exemplar de uma escrita, nomeadamente poética, muito própria. Trata-se do poeta Yao Jingming. Yao é licenciado em Língua e Cultura Portuguesas pela Universidade de Estudos Estrangeiros de Pequim. Nunca deixou de se dedicar à literatura, tendo feito um doutoramento em literatura comparada. Tão-pouco abandonou o português, língua de estudo, que viria a tornar-se, igualmente, língua de afetos e língua de trabalho diário e constante. Além da sua poesia em chinês, sua língua materna, aventurou-se na tradução de poetas lusófonos para chinês, nomeadamente Eugénio de Andrade. Porém, a sua sensibilidade e o profundo conhecimento da língua portuguesa leva-lo-iam a aventurar-se pelo poetizar em português. A sua cumplicidade com a nossa língua é tão marcante, que foi sem peias que alguma da sua poesia foi incluída na coletânea bilingue Poetas Portugueses de Macau / Portuguese Poets of Macau, organizada por Christopher Kelen e Lili Han. No que concerne a sua poesia, o homem Yao Jingming é também conhecido pelo seu nome literário, Yao Feng (姚风). Este “Feng”, o mesmo do tão afamado "fengshui", significa "vento" ou "brisa", pelo que o poeta também goste de se chamar e sentir em português como Yao Brisa.

Sem querer ser (ou parecer!) abusivo, começaria por afirmar que, fruto da cultura em que se cresce, é mais difícil para um poeta chinês despir a camisa da sua "chinesidade"2, do que para muitos poetas do dito mundo ocidental, que mais facilmente despem a sua "ocidentalidade", talvez devido ao fator "internacionalização". Isto é observável, sobretudo, a partir da segunda metade do século XX. Se muita da poesia de Sophia de Mello Breyner ou de

\footnotetext{
${ }^{1}$ Doutorando em Literatura Comparada (Chinesa e Portuguesa) na University of Bristol, Reino Unido. E-mail: gustavo.infante@bristol.ac.uk

${ }^{2}$ Traduzo, assim, o conceito há muito presente na crítica anglófona de "chineseness".
} 
João Cabral de Melo Neto pode ser considerada universal, já a poesia de Yao Jingming tem muitas vezes um pendor local, embora muitos valores universais sobressaiam. Este "pendor local" não quer dizer que seja localizado. Desta feita, são raras as vezes em que a poesia de Yao atenta num aspeto particular, demasiado focalizado. Contudo, a sua poesia revela uma sensibilidade claramente oriental. Afinal, o poeta, esse fazedor de palavras, revela-se naquilo que deixa ecoar até nós. Nele linguagem e cultura são indissociáveis, como de resto para quase todos os chineses, já que o seu sistema de escrita está gráfica e semanticamente imbuído de cultura e linguagem como dois lados da mesma moeda. Essa, porém, é uma consideração que tenho para mim em relação a todos os seres humanos: muito mais do que sermos o que comemos, nós somos a língua em que nos expressamos. Daí que os povos lusófonos, numa língua em que não se consegue viver sem o conjuntivo (ou o subjuntivo, se quiserem), sejam povos de eternas incertezas em que tudo talvez aconteça, se os deuses assim quiserem, um dia, quem sabe. Como os bichos se refugiam nas tocas e grutas, assim nos refugiamos nós nos nossos modos verbais, o que tem consequências políticas, sociais, mas também poéticas.

Este breve estudo incidirá sobre dois poemas escritos por Yao em português, parte da coletânea $A$ noite deita-se comigo. Uma vez que esta coletânea é assinada por Yao ortónimo, referir-me-ei ao poeta como Yao Jingming e não como Yao Feng. Neste poemário há cinco poemas com relação localizada e direta com a China, dos quais dois estão intimamente ligados a Macau, havendo três, portanto, cujo espaço é a China Continental. Nestas páginas apenas dedicarei a minha análise aos dois poemas em que Macau é espaço 'No Cemitério de S. Miguel' (2001, p. 12) e 'Camilo Pessanha' (2001, p. 40).

Como referi acima, Macau é o espaço dos poemas 'No Cemitério de S. Miguel' e 'Camilo Pessanha'. Contudo, uma breve leitura de ambos faz ressaltar um aspeto contrastivo: no primeiro poema Macau é espaço geográfico, ao passo que no segundo a cidade se nos apresenta como espaço literário e espaço de outrem. Em 'No Cemitério de S. Miguel' o eu poético dános como pretexto, mas não necessariamente pré-texto, um verso de Mia Couto: «Só os mortos sabem morrer». Tal verso, retirado de 'Poema da Despedida' ${ }^{3}$, pode ser considerado uma sententia, das muitas com que a obra de Mia Couto nos tem vindo a brindar. Desta forma, antes de lermos o poema, já nos é sugerida uma reflexão sobre a nossa preparação, enquanto seres humanos, para a morte, um acontecimento que tem tanto de inevitável como de evitado. No poema propriamente dito, existe a forte sugestão de que o eu poético se encontra no espaço que nomeia o poema. Assim, de fato, o é. Ao longo de nove versos livres (uma quintilha e uma quadra), o sujeito poético sente e presencia o cemitério como um ser vivo que o cinge num espaço, já

${ }^{3}$ COUTO, 1984, pp. 55-56.

72 fragmentum, N. 35, parte I. Laboratório Corpus: UFSM, Out./ Dez. 2012 
por si, de relativa clausura: «No cemitério | as lápides levantaram-se | para me cercar | como se ao longe na rua | as vozes da vida cercassem o meu ouvido»

Da primeira estrofe, podemos testemunhar que, na verdade, o sujeito poético se encontra triplamente enclausurado: em primeiro lugar, está num cemitério, lá dentro; em segundo lugar, as lápides também o cercam; finalmente, ele sente que as vozes do espaço exterior ao do poema também o cercam. Nesta estrofe é visível a dicotomia entre o fechamento do mundo interior - o cemitério - e o mundo exterior, aqui representado pelas vozes. $\mathrm{O}$ que me parece, sem dúvida, importante nesta estrofe é a presença clara de uma magnânime subversão, uma vez que o horizontal - as lápides - se levanta, tornando-se, assim, vertical. Além disso, o inanimado ganha vida, como é de notar no caso das lápides. Na minha leitura, considero esta sublevação das lápides como um elemento-chave. Contudo, tal movimento ascendente não significa que possamos considerar que o cemitério tivesse deixado de ser um locus amoenus e passado a ser um locus horrendus. Dado que o eu poético se encontra cercado tanto dentro como fora do cemitério, seja pelas lápides ou pelas vozes, o espaço cemiterial está, assim, a um nível tão neutro - ou pelo menos tão igual - quanto o da rua. Não sendo necessariamente prazenteiro, mas muito menos horrendo, classificaria o espaço poético como um locus vivens, pleno de movimento e obtentor de vida.

A razão da sublevação das lápides surge-nos na segunda estrofe: «Não tenho medo de falar com os defuntos $\mid$ que poderão fazer tudo quanto o coração deseja | mas não tenho nada para lhes dizer senão: | Até logo!» $\mathrm{O}$ turbilhão a que o eu poético assiste - instado contra si - é a milenar tentativa de comunicação entre o mundo dos mortos e o dos vivos. Ao compararmos a atitude do eu poético em ambas as estrofes, compreendemos que existe um mecanismo de ação (primeira estrofe) seguido de reação (segunda estrofe), visto que o sujeito do poema reage à rebelião que a ele se dirige. Se na primeira estrofe parece que as lápides estão ao ataque, nas segunda contemplamos um eu poético destemido face a uma possível ameaça, uma vez que ele afirma não ter medo de falar com os mortos. O que é de ressaltar nesta estrofe é a forma em que são classificados estes defuntos: eles «poderão fazer tudo quanto o coração deseja». Também na filosofia chinesa há uma distinção entre alma e coração, muito embora os conceitos possam partilhar algo, mesmo a nível gráfico. Desta feita, tomemos o «coração» stricto sensu, pois, mesmo assim, encontramo-nos num dilema. De quem é este «coração»? Do sujeito poético? $\mathrm{Ou}$, por sinédoque, representa os corações dos defuntos? A ausência de pronome parece-me muito válida, porquanto nos deixe ambas as hipóteses como possíveis. O sujeito do poema poderá considerar que os defuntos poderão realizar tudo aquilo que o seu (dele, sujeito poético) coração deseja, pois, já que estão mortos, inanimados, apenas se tornarão vivos mediante a vontade do coração do eu poético, ou através da sua imaginação. Por outro 
lado, poderemos estar perante a constatação mais básica do sujeito do poema: a de que os mortos - porque estão mortos - podem fazer tudo quanto o coração deles deseja. Ou seja, sugere-se, assim, que o eu poético constata um dos mais velhos topoi literários do mundo - o da morte como fenómeno libertador.

A segunda estrofe encerra em si outros dois tópicos que constituem não só o tema do poema, mas são também topoi atestados ao longo dos séculos, cristalizados tanto nas literaturas ocidentais, como orientais: por um lado, a inutilidade que é ter medo da morte; por outro, o da brevidade da vida. Este último é, sobretudo, visível nos últimos dois versos do poema, em que o poeta confessa apenas poder dizer aos mortos um simples «Até logo!», realçando a emergência do infalível "encontro-passagem" entre o poeta ainda vivo e os defuntos.

Se todos os aspetos referidos anteriormente cabem, por assim dizer, na "caixinha" da cultura, no que diz respeito à linguagem e à relação desta com a cultura há um aspeto a destacar. Mais do que um aspeto é, sim, uma sugestão gráfica com que o poeta nos interpela. Como vimos, o eu poético encontra-se cercado dentro de um cemitério, em confronto visual direto com as lápides e com os defuntos e dando-se conta de que ele próprio, um dia, regressará ao estado de pó. Ora em chinês o caracter “回” (hui), que se nos assemelha como duas cercas, significa precisamente "voltar", "regressar". O encontro do sujeito poético com os mortos testemunha, desta feita, irreversibilidade que existe no ser humano, a de voltar a um estado em que já esteve.

Como referi no início deste breve estudo, a Macau de 'No Cemitério de S. Miguel' é um espaço geográfico, ao passo que a de 'Camilo Pessanha', onde nos deteremos seguidamente, pode ser classificada como espaço literário e espaço do outro, um poema no qual o seu fazedor deixa que outro poeta seja o tema. Deste modo, deixa de haver um eu poético, já que o poeta Yao irá dissertar sobre o poeta Pessanha, tratando-o como objeto poético, um "ele", uma terceira pessoa. Tal como o poema analisado há pouco, 'Camilo Pessanha' é composto de nove versos, desta vez em três dísticos e um terceto. Nele o poeta vivo oferece-nos um breve retrato do poeta morto. O primeiro dístico do poema resume a vida de Pessanha: «Vivia com uma dor | à qual fugiu com uma dor maior». Embora a dor esteja bem presente na sua poesia, considero que as dores referidas neste dístico poderão ser, respectivamente, a dor do pedido de casamento, que fez a Ana de Castro Osório, lhe ter sido declinado e a dor causada pela dependência do ópio. A referência ao ópio é, porém, claríssima na segunda estrofe: «O deserto esgotou-lhe a alma | exilada na aldeia da papoila». Destaca-se o emprego da palavra «deserto», uma excelente metonímia e um suave eufemismo correspondente ao pó de ópio. Se no primeiro dístico encontramos o verbo «fugir», no segundo a ideia de procurar refúgio, neste caso num estupefaciente, surge com maior veemência, já que a 
alma se encontra «exilada» na droga, denotando uma improvável saída do estado letárgico. Nova metonímia, com leves laivos de perífrase, surge-nos na hora de localizar o "exílio" do poeta vivo. Com efeito, este ópio é-nos pintado como um lugar, a «aldeia da papoila». Ou seja, a droga não é somente meio de viagem, mas também, ela própria, o local e o destino. Naturalmente, não será sandeu considerar também a «aldeia da papoila» como uma expressão que designe Macau, cidade onde, de fato, Camilo Pessanha residiu.

A terceira estrofe apresenta-nos o estado adveniente de tal opiofagia: «Perdido no êxtase das nuvens | ignorou o peso do ser e do estar». A viagem proporciona ao poeta morto um «êxtase», que nos é igualmente descrito como um local no qual o poeta «ignorou o peso do ser e do estar». Este segundo verso do dístico, quanto a mim de extrema importância, é revelador do apreço e reconhecimento que o poeta vivo tem pelo poeta morto, porquanto reconheça que ele, Pessanha, teve um peso na poesia em língua portuguesa de que ele próprio nunca se dera conta quando vivo, nem de forma perene («ser») nem de forma breve («estar»). A estrofe final relembra-nos o fruto - e consequência - do árduo labor do poeta: «Na fenda entre o sono e o sonho | resta a poesia a gotejar da clepsidra | ao longo da viola morosa». Neste terceto final há dois aspetos dignos de nota. Em primeiro lugar, a «fenda» que Yao traz até nós é esse lugar exíguo onde reside a poesia de Camilo Pessanha. Porém, essa «fenda» encontra-se «entre o sono e o sonho», ou seja, num finíssimo limbo em que nos é permitido saborear a sua poesia ao lê-la, possivelmente à mercê do ópio, também ele veículo que nos leva ao lugar «entre o sono e o sonho». Teçamos uma segunda consideração ao atentarmos para a beleza com que o poeta vivo se refere à poesia de Pessanha como uma poesia que goteja, qual areia, dentro da «clepsidra». Neste verso é clara a referência ao Clepsidra, o livro de poemas que Camilo Pessanha, embora não por sua mão, nos deixaria. A presença de uma «viola morosa» poderá remeter para o fado como sinónimo de destino, ou de vida; ou simplesmente, numa hipálage, para uma melodia morosa numa viola, que a toca à guisa de acompanhamento à fruição dos poemas. A possível interpretação da «viola morosa» como referência ao fado não é tão descabida se tivermos em linha de conta que na coletânea há toda uma secção dedicada a Portugal, havendo, inclusive, um poema intitulado 'Fado para uma festa' (2001, p. 81), no qual se celebram a música, a noite e a intimidade.

Para concluir a análise destes dois poemas, gostaria de mencionar, a título de curiosidade, que, embora os dois poemas não sejam contíguos na coletânea onde estão incluídos, não havendo, portanto, uma sucessão lógica do primeiro para o segundo, parece existir entre eles um fio condutor, se recordarmos que Camilo Pessanha se encontra sepultado no Cemitério de S. Miguel, em Macau. 
Como mencionei no início deste pequeno estudo, além dos poemas em que Macau é espaço, há outros três em que a China Continental ocupa o tema e o poema. Embora não os analise aqui, gostaria de deixar algumas notas em relação a eles. Estes três poemas surgem arrumados no livro de forma contígua, como se de um tríptico se tratasse. Pelos títulos dos poemas, reparamos também a escolha incidiu em organizá-los dum espaço geral para um espaço mais particular, segundo o costume chinês. Temos assim: 'Na minha pátria' (p. 56), 'Grande Muralha' (p. 57) e 'Praça do Povo' (p. 58). Em todos três, o poeta volta a ser o sujeito do poema, apropriando-se do espaço e do que nele existe. Esse espaço, como tudo o que nele se vê incluído, é indubitavelmente parte da cultura. De fato, a geometria de uma cidade como Pequim é a mesma geometria que está na base dos caracteres chineses, instrumento essencial da expressão. Yao Jingming, na sua poesia, oferece-nos de todos esses elementos: do reto, ao curvilíneo; do eu à alteridade; e não raras vezes sublinhando quão etéreo e fugaz é cada momento poetizado. Todos estes elementos souberam sobreviver e permanecer em Macau enquanto local muitas vezes descrito como híbrido, o que faz da cidade um espaço, em certa medida, único.

Macau como espaço literário - no qual insiro, naturalmente, Yao Jingming - é algo que eu classificaria como espaço em mutação. Talvez seja ousado dizer que é um espaço literário à procura de si. Contudo, é um espaço - como poucos! - que pode afirmar-se numa plenitude de expressões linguísticas. Monica Simas refere que «a produção textual colonial tratou Macau como um território conceitual pensado no espaço periférico de reprodução de uma consciência nacional» (2007, p. 129). Passada a época da administração portuguesa, ficaram - e ficarão, espero - as literaturas de Macau. Literaturas - plural - por assim se fazer corresponder às diferentes línguas em que essa literatura é escrita: chinês, inglês, português, ou até tagalog, dada a visível comunidade filipina. Ficarão, seguramente, as sementes de algo que poderá vir a enraizar-se e a canonizar-se como uma literatura chinesa de expressão portuguesa, seja essa designação apresentada como justificação de origem étnica - na qual colocaríamos Yao Jingming - seja como justificação geográfica e política, visto que em 2049 o território da Região Administrativa Especial de Macau passará a integrar, na sua plenitude, a República Popular da China, deixando de patentear o seu estatuto de região administrativa especial.

76 fragmentum, N. 35, parte I. Laboratório Corpus: UFSM, Out./ Dez. 2012 


\section{Referências}

COUTO, Mia. Raiz de Orvalho e outros poemas; O fio das missangas. Lisboa: Caminho, 1984.

KELEN, Christopher, e Lili HAN (Org.). Poetas Portugueses de Macau / Portuguese Poets of Macau. 2. ed. Macau: ASM - Association of Stories in Macao, 2010.

SIMAS, Monica. Margens do Destino: Macau e a literatura em língua portuguesa. São Caetano do Sul, SP: Yendis, 2007.

YAO, Jingming. A noite deita-se comigo. Guimarães: Pedra Formosa Associação Cultural e Instituto Internacional de Macau, 2001. 